\title{
Comparative Sorption and Leaching Study of the Herbicides Fluometuron and 4-Chloro-2-methylphenoxyacetic Acid (MCPA) in a Soil Amended with Biochars and Other Sorbents
}

\author{
Alegria Cabrera, ${ }^{*, \dagger}$ Lucia Cox, ${ }^{\S}$ Kurt A. Spokas, ${ }^{\ddagger}$ Rafael Celis, ${ }^{\S}$ M. Carmen Hermosín, ${ }^{\S}$ Juan Cornejo, ${ }^{\S}$ and \\ William C. Koskinen ${ }^{\ddagger}$ \\ ${ }^{\dagger}$ Department of Soil, Water, and Climate, University of Minnesota, 439 Borlaug Hall, 1991 Upper Buford Circle, St. Paul, \\ Minnesota 55108, United States

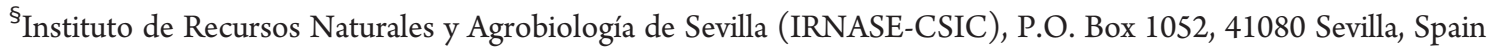 \\ ${ }^{\ddagger}$ Agricultural Research Service, U.S. Department of Agriculture, 439 Borlaug Hall, 1991 Upper Buford Circle, St. Paul, Minnesota 55108, \\ United States
}

ABSTRACT: Biochar, the solid residual remaining after the thermochemical transformation of biomass for carbon sequestration, has been proposed to be used as a soil amendment, because of its agronomic benefits. The effect of amending soil with six biochars made from different feedstocks on the sorption and leaching of fluometuron and 4-chloro-2-methylphenoxyacetic acid (MCPA) was compared to the effect of other sorbents: an activated carbon, a Ca-rich Arizona montmorillonite modified with hexadecyltrimethylammonium organic cation (SA-HDTMA), and an agricultural organic residue from olive oil production (OOW). Soil was amended at $2 \%(\mathrm{w} / \mathrm{w})$, and studies were performed following a batch equilibration procedure. Sorption of both herbicides increased in all amended soils, but decreased in soil amended with a biochar produced from macadamia nut shells made with fast pyrolysis. Lower leaching of the herbicides was observed in the soils amended with the biochars with higher surface areas BC5 and BC6 and the organoclay $(\mathrm{OCl})$. Despite the increase in herbicide sorption in soils amended with two hardwood biochars (BC1 and $\mathrm{BC} 3)$ and OOW, leaching of fluometuron and MCPA was enhanced with the addition of these amendments as compared to the unamended soil. The increased leaching is due to some amendments' soluble organic compounds, which compete or associate with herbicide molecules, enhancing their soil mobility. Thus, the results indicate that not all biochar amendments will increase sorption and decrease leaching of fluometuron and MCPA. Furthermore, the amount and composition of the organic carbon (OC) content of the amendment, especially the soluble part (DOC), can play an important role in the sorption and leaching of these herbicides.

KEYWORDS: amendment, biochar, dissolved organic carbon, fluometuron, herbicides, leaching, MCPA, olive oil mill waste, organoclay, pesticides, soil, sorption

\section{INTRODUCTION}

Large amounts of pesticides are used on agricultural soils worldwide because they increase crop yields, ensuring an abundant and affordable food supply. However, the risk of surface water and groundwater contamination is of concern because of the potential negative consequences for human health and the environment. ${ }^{1}$ Therefore, it is essential to know and understand the fate of pesticides in soil prior to implementing pest management strategies.

Fluometuron ( $N, N$-dimethyl- $N^{\prime}$-[3-(trifluoromethyl)phenyl]urea) is a phenylurea herbicide used for the pre-emergence and early postemergence control of weeds in cotton crops. Sorption of fluometuron is influenced by the organic matter (OM) content of the soil, ${ }^{2}$ and high mobility and leaching of the herbicide has been reported for soils with low OM content. ${ }^{2,3}$ According to Baskaran and Kennedy, ${ }^{4}$ this herbicide can leach through permeable and sandy soils and may result in groundwater contamination.

MCPA (4-chloro-2-methylphenoxyacetic acid) is a weak acid herbicide used for the control of a broad spectrum of weeds in pre-emergence in a variety of crops. At natural agricultural soil $\mathrm{pH}$ levels, MCPA is in the anionic form and, as other anionic herbicides, is weakly sorbed to soil. Thus, MCPA is highly mobile, with runoff and leaching risks for surface water and groundwater. $^{5}$

The addition of a variety of organic amendments to agricultural soils is a common practice to increase soil OM content. Biochar, the solid residue remaining after the thermochemical transformation of biomass, has been recently proposed as soil amendment, ${ }^{6}$ because of its high stability against decay in soil environments ${ }^{7}$ and its apparent ability to influence the availability of nutrients as compared to other soil organic amendments. Biochar is considered to be more biologically inert as compared to other forms of organic $\mathrm{C}$ in soil due to its highly condensed aromatic structure. ${ }^{8}$ Therefore, biochar applications can simultaneously achieve both $\mathrm{C}$ sequestration and soil fertility improvements. The effects of the use of biochar as soil amendment on soil properties have been extensively studied and reported.,10

Other organic wastes have also been suggested as soil amendments, such as sewage sludge, spent mushroom substrates, and

Received: July 7, 2011

Revised: October 7, 2011

Accepted: October 24, 2011

Published: October 24, 2011 


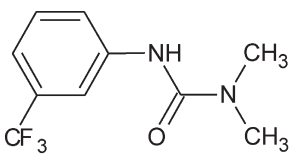

Fluometuron

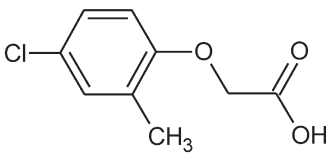

MCPA
Figure 1. Chemical structures of the herbicides fluometuron and MCPA.

urban wasted, and olive mill and winery wastes. These additions have been shown to increase sorption of pesticides. ${ }^{11-14}$ These amendments have also been shown to influence other pesticide soil processes, such as leaching and degradation. ${ }^{12,15}$ In contrast, there are few studies about the impacts of biochar on pesticide fate in soils. ${ }^{16,17}$ Addition of biochar has been shown to increase sorption and to decrease the dissipation of pesticides in soils. ${ }^{18-20}$ For these reasons, biochar could be postulated as an amendment to potentially reduce the contamination risks of surface water and groundwater if mixed with soils as inmobilization zone, which is the hypothesis of this work.

The aim of this work was to assess the potential of several biochars made from different feedstocks under different pyrolysis conditions to increase the sorption and reduce the vertical mobility of the herbicides fluometuron and MCPA in a sandy soil. These herbicides were selected for the study due to their wide use in common crops, such as cotton, cereals, olives, and vines, and the high mobility and leaching risk reported for both herbicides. The biochars were also compared with other proposed soil amendments, such as activated carbon, olive mill waste (OOW), and an organically modified clay. OOW is a solid waste produced by the two-phase centrifugation process for the olive oil extraction. This waste is rich in OM, and its use as soil amendment is an efficient method for its disposal and has been shown to increase the sorption of herbicides. ${ }^{13,21-24}$ Organoclays (OCls) are natural mineral clays, in which the inorganic exchange cation has been replaced with organic cations. The use of OCls has been proposed to reduce the risk of transport of organic contaminants from soil ${ }^{25}$ and recently as soil amendments $^{26}$ to improve the fate of herbicides in soils.

\section{MATERIALS AND METHODS}

Herbicides. Fluometuron (Figure 1) is a substituted urea, which has a water solubility of $105 \mathrm{mg} \mathrm{L}^{-1}$ at $20^{\circ} \mathrm{C}$ and $\mathrm{pH} \mathrm{7.}{ }^{27}$ Pure analytical fluometuron (purity $=99.5 \%$ ) purchased from Sigma-Aldrich (Spain) was used to prepare the external standards for fluometuron analysis and the initial solutions used in the batch sorption experiments. Commercial fluometuron (Dinagam Linz, 50\% suspension concentrate) from Bayer (Spain) was used in the column leaching experiments. MCPA (Figure 1) is a weak acid with a water solubility of $293.9 \mathrm{mg} \mathrm{L}^{-1}$ at $25^{\circ} \mathrm{C}$ and $\mathrm{pH} 7 .{ }^{27}$ Analytical grade MCPA (purity $=98.9 \%$ ) from Riedel-de Haën (Germany) was used to prepare the initial herbicide solutions used in the adsorption and leaching experiments and the external standards for herbicide analysis.

Amendments. Six different biochars, ranging in characteristics and origins, were used as sorbents (Table 1). Two biochars were activated by thermal (BC4) and chemical (BC6) processes to study if biochar activation increases their sorptive properties. Thermal activation was achieved by heating the biochar to $200{ }^{\circ} \mathrm{C}$ in the presence of atmospheric oxygen for $24 \mathrm{~h}$. Chemical activation for BC6 was obtained by a $24 \mathrm{~h}$ soaking in $3 \%$ hydrogen peroxide $\left(\mathrm{H}_{2} \mathrm{O}_{2}\right)$, which was following by air-drying to remove easily oxidized organics. Biochars were characterized by total elemental composition (Ultimate Analysis, ASTM D3176-09). The specific surface area of biochar was measured by nitrogen surface sorption, using a Carlo Erba Sorptomatic 1900 and the Brunauer, Emmett, and Teller (BET) method on $0.2 \mathrm{~g}$ of previously degassed sample at $80^{\circ} \mathrm{C}$ during $24 \mathrm{~h}$. The untreated biochars had the lowest surface areas $\left(3.3-46 \mathrm{~m}^{2} \mathrm{~g}^{-1}\right)$, whereas the activated charcoal possessed a surface area of $979 \mathrm{~m}^{2} \mathrm{~g}^{-1}$.

The $\mathrm{pH}$ was determined by a 1:5 biochar to deionized water slurry. The $\mathrm{pH}$ values for the biochars ranged from 5.5 to 8.0. Carbon contents were determined with ASTM method D5373-08 and correspondingly ranged from 44 to $95 \%$; nitrogen contents ranged from 0.3 to $1.3 \%$.

Dissolved organic carbon (DOC) from amendments was characterized and extracted by treatment of $1 \mathrm{~g}$ of the sorbent with $20 \mathrm{~mL}$ of $0.01 \mathrm{M}$ $\mathrm{CaCl}_{2}$. Suspensions were shaken overnight, centrifuged at $10000 \mathrm{rpm}$ during $10 \mathrm{~min}$, and filtered through a $0.45 \mu \mathrm{m}$ pore nylon filter. DOC of the extracts was measured with a Shimadzu-V csh analyzer.

The OCl was synthesized by modifiying Ca-rich Arizona montmorillonite (Clay Minerals Society, Purdue University) with the organic cation hexadecyltrimethylammonium (HDTMA). Modification was carried out through an ion exchange reaction by treating $10 \mathrm{~g}$ of the montmorillonite with $100 \mathrm{~mL}$ of an ethanol/water (50:50) solution containing an amount of the organic cation equal to the CEC of the clay $\left(\mathrm{CEC}=120 \mathrm{cmol} \mathrm{kg}^{-1}\right)$. The suspension was shaken for $24 \mathrm{~h}$, centrifuged, washed with distilled water until $\mathrm{Cl}$-free, and then lyophilized. Organic cation was supplied by Sigma-Aldrich as high-purity chloride salt (purity > 98\%).

The OOW was kindly supplied by the experimental olive oil mill IFAPA Venta del Llano, located in Mengíbar (Jaén, Spain). To reduce its high moisture content, the OOW was air-dried prior to use. Properties of the waste were as follows: $\mathrm{pH} 5.8, \mathrm{OM} 92 \%$, and C:N ratio 39.

Soil. The soil used was a sandy loam soil with $79 \%$ sand, $8 \%$ silt, and $13 \%$ clay; it has an OC content of $0.25 \%, 0.43 \%$ OM, $0.03 \% \mathrm{~N}$ org, and $\mathrm{C} / \mathrm{N}$ ratio equal to 8 . This soil was located in the experimental farm of IRNAS (Coria del Río, Sevilla, Spain) and devoted to olive groves. Soil was amended at a rate of $2 \%(\mathrm{w} / \mathrm{w})$ with the sorbent for the sorptiondesorption experiments. Soil and amendments were thoroughly mixed and sieved with a $2 \mathrm{~mm}$ mesh sieve. OC content of the amended soils increased in a range of $0.69-2.14 \%$, depending on the amendment and according to the $2 \% \mathrm{w} / \mathrm{w}$ amending rate.

Sorption-Desorption Experiments. Duplicate samples ( $2.5 \mathrm{~g})$ of unamended and $2 \%(\mathrm{w} / \mathrm{w})$ amended soils were treated with $5 \mathrm{~mL}$ of fluometuron and MCPA solutions (initial concentrations, $C_{\mathrm{i}}$, ranged from 1 to $20 \mathrm{mg} \mathrm{L}^{-1}$ in $0.01 \mathrm{M} \mathrm{CaCl}_{2}$ ). Previously, it was determined that equilibrium was reached in $<24 \mathrm{~h}$ and that no measurable degradation occurred during this period. Equilibrium concentrations $\left(C_{\mathrm{e}}\right)$ in the supernatants after $24 \mathrm{~h}$ of equilibration time were determined by HPLC with a Waters 600E chromatograph coupled to a Waters 996 diode array detector, under the following conditions: Nova-Pak column, $150 \mathrm{~mm}$

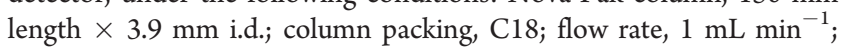
$25 \mu \mathrm{L}$ injection; eluent system for fluometuron 60:40 (v/v) water/ acetonitrile mixture and UV detection at $243 \mathrm{~nm}$; eluent system for MCPA 60:40 (v/v) methanol/diluted $\mathrm{H}_{3} \mathrm{PO}_{4}(\mathrm{pH} 2)$ mixture and UV detection at $230 \mathrm{~nm}$. Differences between $C_{\mathrm{i}}$ and $C_{\mathrm{e}}$ were assumed to be the amounts sorbed $\left(C_{s}\right)$. Sorption isotherms were fitted to the Freundlich equation, $C_{\mathrm{s}}=K_{\mathrm{f}} C_{\mathrm{e}}{ }^{1 / n f}$, and sorption coefficients $K_{\mathrm{f}}$ and $1 / n f$ calculated. $K_{\mathrm{d}}-15$ was calculated as $C_{\mathrm{s}} / C_{\mathrm{e}}$ at $15 \mathrm{mg} \mathrm{L}^{-1}$ as $C_{\mathrm{e}}$. Herbicide desorption was made with successive washings (three times) with $0.01 \mathrm{M} \mathrm{CaCl}_{2}$ of the soil that was initially equilibrated with $20 \mathrm{mg} \mathrm{L}^{-1}$ herbicide concentration for $24 \mathrm{~h}$. The hysteresis coefficient was determined as $H=\left(1 / n f_{\text {des }}\right) /\left(1 / n f_{\text {ads }}\right)$.

Leaching Experiments. Duplicate columns $(3.1 \mathrm{~cm}$ i.d.) were hand-packed with $150 \mathrm{~g}$ of unamended soils to a height of $20 \mathrm{~cm}$ soil in each column. To study the amendment effect on leaching, $10 \mathrm{~g}$ of soil amended with $2 \%$ of sorbent was placed at the top of the soil. Glass wool was placed at the bottom of the column to avoid soil losses, and sea sand was added at the top of the soil or amended soil. After saturation of the 
Table 1. Chemical and Physical Properties of the Amendments ${ }^{a}$

\begin{tabular}{|c|c|c|c|c|c|c|c|}
\hline $\begin{array}{c}\text { amend- } \\
\text { ment }\end{array}$ & feedstock & $\begin{array}{l}\text { production } \\
\text { temperature } \\
\quad\left({ }^{\circ} \mathrm{C}\right)\end{array}$ & $\mathrm{pH}$ & \% C & SSA $\left(\mathrm{m}^{2} \mathrm{~g}^{-1}\right)$ & $\% \mathrm{~N}$ & $\operatorname{DOC}\left(\mathrm{mg} \mathrm{L}^{-1}\right)$ \\
\hline $\mathrm{BC} 1$ & hardwood sawdust & 500 (fast pyrolysis) & 8.0 & 61.8 & 6.2 & 0.3 & $118 \pm 46$ \\
\hline $\mathrm{BC} 2$ & macadmia nut shells & 850 (flash pyrolysis) & 6.2 & 77.7 & 3.3 & 0.6 & $352 \pm 29$ \\
\hline $\mathrm{BC} 3$ & hardwood (oak/hickory) & 540 & 6.6 & 73.3 & 8.0 & 0.3 & $64 \pm 38$ \\
\hline $\mathrm{BC} 4$ & hardwood (oak/hickory) & $540\left(+\right.$ thermal activation $\left.200^{\circ} \mathrm{C}, 2 \mathrm{~h}\right)$ & 6.8 & 43.9 & 5.9 & 0.7 & $31 \pm 0.2$ \\
\hline $\mathrm{BC5}$ & wood pellets & $>500$ (slow pyrolysis) $(<2 \mathrm{~mm}$ particle size $)$ & 5.5 & 77.3 & 46 & 0.4 & $48 \pm 1.5$ \\
\hline BC6 & wood pellets & $>500+\mathrm{H}_{2} \mathrm{O}_{2}$ activation $(>2 \mathrm{~mm}$ particle size $)$ & 9.8 & 69.3 & 16 & 0.2 & $38 \pm 0.5$ \\
\hline $\mathrm{AC}$ & bituminous coal & $800(+$ steam activation $)$ & 6.7 & 94.9 & 979 & 1.3 & $3.0 \pm 0.4$ \\
\hline $\mathrm{OCl}$ & organoclay & $\mathrm{n} / \mathrm{a}$ & 6.5 & 22.5 & 20 & 1.3 & $5.4 \pm 0.8$ \\
\hline oow & olive oil waste & $\mathrm{n} / \mathrm{a}$ & 5.8 & 53.2 & 17 & 1.2 & $341 \pm 17$ \\
\hline
\end{tabular}

${ }^{a}$ SSA, specific surface area; DOC, dissolved organic carbon; n/a, not applicable. The amendments were obtained from the following suppliers: BC1, Dynamotive (CQuest); BC2, Biochar Brokers; BC3, Cowboy Charcoal; BC4, activated by the USDA-ARS, St. Paul, MN; BC5, Chip Energy; BC6, activated by the USDA-ARS, St. Paul, MN; OCl, The Clays Mineral Society (Purdue University); AC, Siemens (Aquacarb 816); OOW, IFAPA Venta del Llano.

soils with $0.01 \mathrm{M} \mathrm{CaCl}_{2}$, solutions of fluometuron or MCPA in methanol were added to the soil in the column at a rate of $2 \mathrm{~kg} \mathrm{ha}^{-1}(0.15 \mathrm{mg}$ ai $)$. After $24 \mathrm{~h}$, enough time for the methanol to evaporate, $10 \mathrm{~mL}$ of $0.01 \mathrm{M}$ $\mathrm{CaCl}_{2}$ was added daily and the leachates were collected during 30 days. The leachates were analyzed by HPLC, as previously described. At the end of the leaching study, soil was extracted from the columns aided by $\mathrm{N}_{2}$ gas and sectioned into $5 \mathrm{~cm}$ increments corresponding to different depths; fluometuron was extracted with methanol and MCPA with a mixture of 60:40 (v/v) methanol/diluted $\mathrm{H}_{3} \mathrm{PO}_{4}(\mathrm{pH} 2)$. Extracts were centrifuged, filtered, and analyzed by HPLC as previously described. The percentage of the herbicides leached was plotted against the volume added to obtain the breakthrough and cumulative breakthrough curves.

\section{RESULTS AND DISCUSSION}

Sorption-Desorption Experiments. Fluometuron. Sorption isotherms are shown in Figure 2 and Freundlich sorption and desorption coefficients in Table 2. From Figure 2 it is observed that soil + amendment mixtures resulted in three levels of isotherms: high sorption $(\mathrm{S}+\mathrm{AC}, \mathrm{S}+\mathrm{OCl}, \mathrm{S}+\mathrm{BC} 5$, and $\mathrm{S}+\mathrm{BC} 6)$, medium sorption $(\mathrm{S}+\mathrm{BC} 1, \mathrm{~S}+\mathrm{BC} 3$, and $\mathrm{S}+\mathrm{BC} 4)$; and low sorption (S+OOW and $\mathrm{S}+\mathrm{BC} 2)$. Unamended soil also had low sorption. With the exception of isotherms corresponding to soil with $\mathrm{AC}$ and $\mathrm{OCl}$, all isotherms were of $\mathrm{L}$ type. Sorption data fit the Freundlich equation $\left(R^{2}=0.917-0.997\right)$. Fluometuron was completely sorbed in the soil amended with the activated carbon, and data could not be fitted to the Freundlich equation. The slopes of the isotherms $(1 / n f)$ are lower than unity, which means that sorption is highly dependent on initial solution concentration, with proportionally higher sorption at lower concentration as compared to higher concentrations. ${ }^{28}$

The fluometuron $K_{\mathrm{f}}$ value in the unamended soil was 0.44 (Table 2), slightly lower than values reported in the literature of $0.56-1.29$ for soils with $0.65-1.27 \%$ OC content ${ }^{4}$ and $1.04-$ 2.18 for conventional tillage surface soil with $0.4-2 \%$ OC content and $0-25 \mathrm{~cm}$ depth, ${ }^{29}$ but in the order of data reported by Locke et al., ${ }^{30} K_{\mathrm{f}}$ values of $0.42-1.56$ on conventional tillage surface with $0.46-1.13 \%$ OC. Due to the fact that $1 / n f$ values were not equal, $K_{\mathrm{d}}-15$ (sorption coefficients at $C_{\mathrm{e}}=15 \mathrm{mg} \mathrm{L}^{-1}$ ) values were used to compare sorption of fluometuron (Table 2) and followed the trend $\mathrm{S}+\mathrm{OCl}>\mathrm{S}+\mathrm{BC} 5>\mathrm{S}+\mathrm{BC} 6>\mathrm{S}+\mathrm{BC} 4>$ $\mathrm{S}+\mathrm{BC} 3 \geq \mathrm{S}+\mathrm{BC} 1>\mathrm{S}+\mathrm{OOW}>\mathrm{S}+\mathrm{BC} 2>\mathrm{S}$.
Sorption of fluometuron is related to the DOC content and the surface area of biochar. High sorption of fluometuron was observed in the soil amended with BC5 and BC6, the surface areas of which were 46 and $16.2 \mathrm{~m}^{2} \mathrm{~g}^{-1}$, respectively. However, lower sorption of fluometuron was observed in the soil amended with $\mathrm{BC} 2$, with the higher content on DOC $\left(352 \mathrm{mg} \mathrm{L}^{-1}\right)$ and lowest surface area $\left(3.29 \mathrm{~m}^{2} \mathrm{~g}^{-1}\right)$ (Table 1$)$. The low sorption of fluometuron can be attributed to the competition between the DOC and herbicide molecules for sorption sites and by interactions in solution between fluometuron and the DOC, as was reported for diuron, another substituted urea herbicide, by Cox et al. ${ }^{31}$ DOC on soil also modifies the hydrophobic and/ or hydrophilic character of the soil, reducing its affinity for pesticide sorption. ${ }^{32} \mathrm{Yu}$ et al. ${ }^{20}$ related the sorption of the fungicide pyrimethanil in a sandy loam soil amended with biochar to the specific surface area (SSA) of the amendment. These authors reported higher sorption of the fungicide in the soil amended with the biochar with higher SSA. Also, BC5 and BC6 are produced from wood pellets in a slow pyrolysis limited-aerobic process, which were separated by sieving $(>2$ and $<2 \mathrm{~mm}$ ), yielding fractions of the same biochar with different particle sizes. BC5 is the lower particle size $(<2 \mathrm{~mm})$ and BC6 is the biochar of higher particle size $(>2 \mathrm{~mm})$, which was also activated with $3 \%$ hydrogen peroxide $\left(\mathrm{H}_{2} \mathrm{O}_{2}\right)$. Despite the biochar activation, higher sorption of fluometuron was observed in the soil amended with the biochar with lower particle size and, hence, higher SSA (BC5) (Table 1).

Sorption of fluometuron on the soil amended with the modified clay was even higher than in the soils amended with biochars; a 1.8-25.2-fold increase was observed for the $K_{\mathrm{d}}-15$ values (Table 2). Fluometuron $K_{\mathrm{d}}-15$ calculated for the soil amended with the organoclay was 5.6, a 31-fold increase as compared to the unamended soil. A high affinity of the herbicide fluometuron for the organoclay SA-HDTMA has been reported ${ }^{26}$ and attributed to hydrophobic interactions between fluometuron and the alkyl chains of HDTMA cations.

When OOW was studied as a fluometuron sorbent in soil, only a slight increase in sorption was observed as compared to the unamended soil, a 1.4-fold increase for $K_{\mathrm{d}}$ value and a 1.7-fold increase for $K_{\mathrm{f}}$ (Table 2). OOW has been observed to increase diuron, another phenylurea herbicide, sorption. ${ }^{13,21,33}$ Whereas OOW is considered to be a good amendment for soils because 

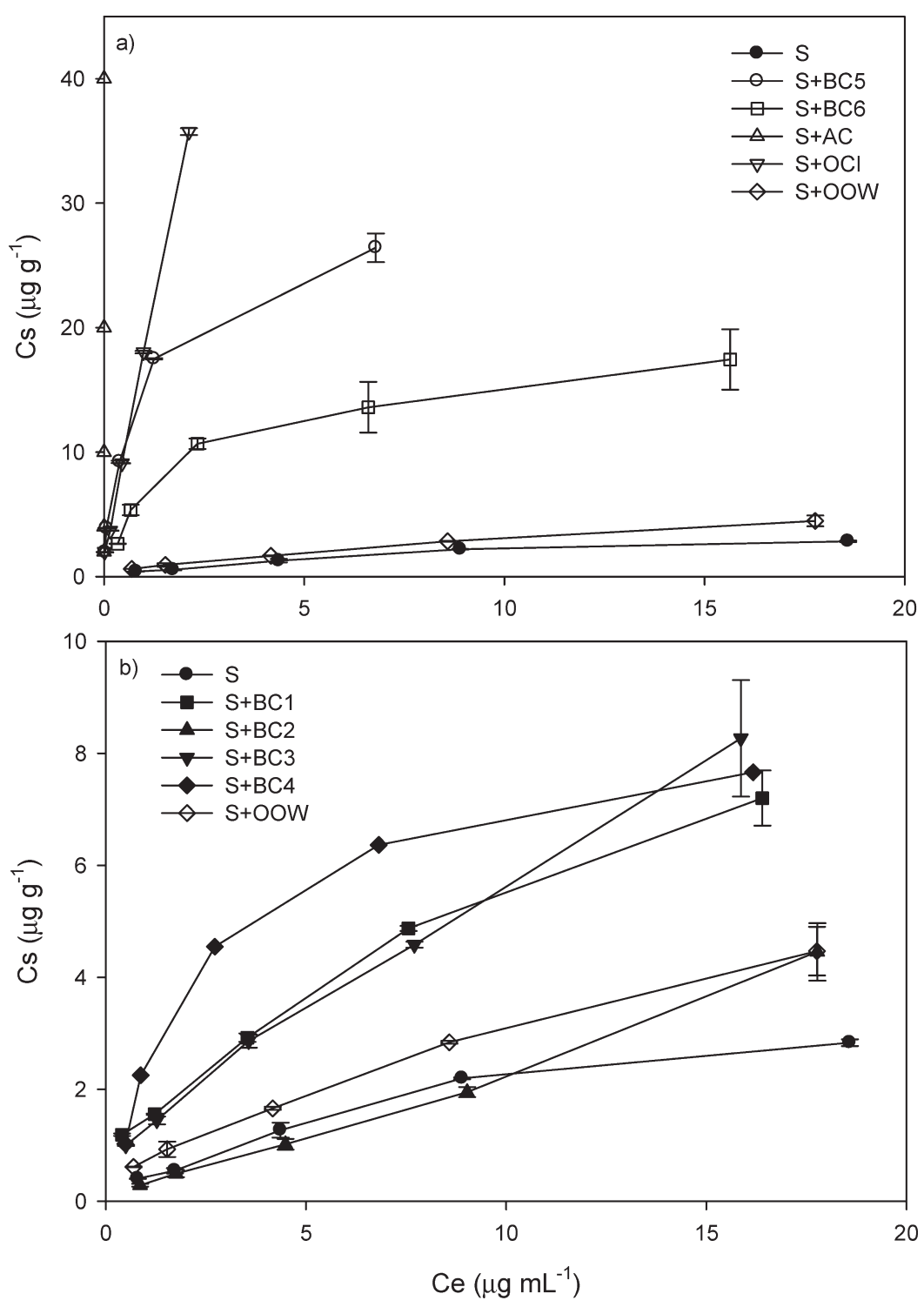

Figure 2. (a) Sorption isotherms of fluometuron on unamended soil and soil amended with biochars, organoclay, olive mill waste, and activated carbon. b) Sorption isotherms of fluometuron on unamended soil and soil amended with biochars and olive mill waste.

Table 2. Sorption-Desorption Coefficients of Fluometuron in Unamended Soil and Soil Amended with Different Biochars, Organoclay, Olive Mill Waste, and Activated Carbon

\begin{tabular}{|c|c|c|c|c|c|c|c|c|}
\hline soil & $K_{\mathrm{f}}\left(\mathrm{mg}^{1-1 / n f} \mathrm{~L}^{1 / n f} \mathrm{~kg}^{-1}\right)$ & $1 / n f$ & $R^{2}$ & $K_{\mathrm{d}^{-1}} 15\left(\mathrm{~L} \mathrm{~kg}^{-1}\right)$ & $K_{\text {fdes }}\left(\mathrm{mg}^{1-1 / n f} \mathrm{~L}^{1 / n f} \mathrm{~kg}^{-1}\right)$ & $1 / n f_{\text {des }}$ & $R^{2}$ & $\mathrm{H}$ \\
\hline$S$ & $0.44(0.40-0.49)$ & $0.67 \pm 0.06$ & 0.979 & $0.18(0.16-0.20)$ & $1.1(0.9-1.3)$ & $0.36 \pm 0.08$ & 0.917 & 0.53 \\
\hline $\mathrm{S}+\mathrm{BC} 1$ & $1.65(1.53-1.78)$ & $0.51 \pm 0.05$ & 0.977 & $0.44(0.41-0.47)$ & $7.3(6.6-7.9)$ & $0.02 \pm 0.05$ & 0.048 & 0.03 \\
\hline $\mathrm{S}+\mathrm{BC} 2$ & $0.30(0.28-0.33)$ & $0.89 \pm 0.05$ & 0.990 & $0.22(0.20-0.25)$ & $1.2(1.2-1.3)$ & $0.46 \pm 0.02$ & 0.995 & 0.52 \\
\hline $\mathrm{S}+\mathrm{BC} 3$ & $1.38(1.29-1.47)$ & $0.61 \pm 0.04$ & 0.988 & $0.48(0.45-0.52)$ & $6.2(5.8-6.7)$ & $0.11 \pm 0.03$ & 0.847 & 0.19 \\
\hline $\mathrm{S}+\mathrm{BC} 4$ & $2.04(1.75-2.38)$ & $0.55 \pm 0.10$ & 0.917 & $0.61(0.52-0.71)$ & $7.0(6.9-7.1)$ & $0.04 \pm 0.01$ & 0.882 & 0.07 \\
\hline $\mathrm{S}+\mathrm{BC} 5$ & $13.1(11.8-14.5)$ & $0.47 \pm 0.05$ & 0.973 & $3.07(2.77-3.41)$ & $26.9(26.8-26.9)$ & 0 & 0.770 & 0 \\
\hline S+BC6 & $5.58(4.94-6.30)$ & $0.47 \pm 0.08$ & 0.929 & $1.33(1.18-1.50)$ & $16.0(15.8-16.2)$ & $0.03 \pm 0.01$ & 0.902 & 0.06 \\
\hline \multicolumn{9}{|l|}{$\mathrm{S}+\mathrm{AC}$} \\
\hline $\mathrm{S}+\mathrm{OCl}$ & $17.2(14.1-21.1)$ & $0.59 \pm 0.10$ & 0.925 & $5.60(4.57-6.86)$ & $28.3(27.3-29.4)$ & $0.32 \pm 0.07$ & 0.921 & 0.54 \\
\hline S+OOW & $0.74(0.71-0.76)$ & $0.62 \pm 0.02$ & 0.997 & $0.26(0.25-0.27)$ & $1.6(1.4-1.9)$ & $0.38 \pm 0.08$ & 0.916 & 0.61 \\
\hline
\end{tabular}

of the increase in the soil organic matter content, this amendment's impact on fluometuron sorption is lower as compared to biochars (except for BC2) and to diuron. In the case of diuron sorption, the percentage of amendment used was $5-10 \%,{ }^{13,21,33}$ 

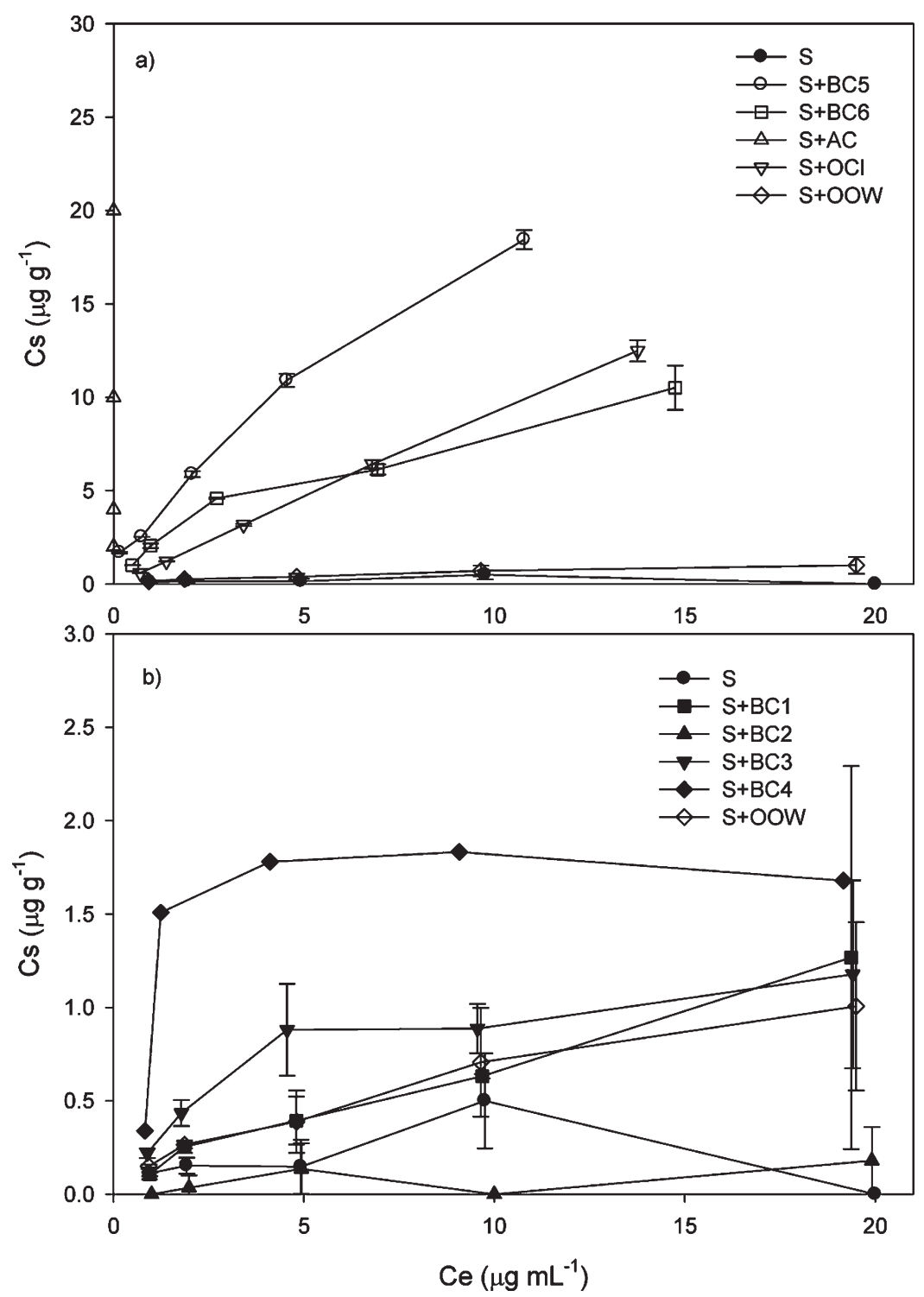

Figure 3. (a) Sorption isotherms of MCPA on unamended soil and soil amended with biochars, organoclay, olive mill waste, and activated carbon. (b) Sorption isotherms of MCPA on unamended soil and soil amended with biochars and olive mill waste.

instead of the $2 \%$ used in this study. Baskaran and Kennedy ${ }^{4}$ and Gámiz et $\mathrm{al}^{26}$ reported higher sorption of diuron than of fluometuron on soil and organoclays, respectively, under the same experimental conditions, due to higher water solubility of fluometuron as compared to diuron. As in the case of BC2, the high content in DOC of OOW should also contribute to this low sorption.

Fluometuron desorption was hysteretic for all samples $\left(1 / n f_{\text {des }}<\right.$ $1 / n f_{\text {ads }}$ ) (Table 2 ), which means it is very difficult to desorb a significant amount of the sorbed herbicide and that desorption cannot be predicted accurately from sorption isotherms. ${ }^{34}$ The irreversibility of the sorption process increased with the addition of biochar to soil, except for $\mathrm{BC} 2$ and $\mathrm{OCl}$, as can be observed in the decrease of the hysteresis coefficient $(H)$ (Table 2). The use of OOW as sorbent increased the reversibility of fluometuron sorption as compared to the nonamended soil. In the case of organoclay $^{35}$ and OOW, ${ }^{13}$ the enhanced sorption is due to the combination of polar and hydrophobic interactions, which could favor sorption reversibility.
MCPA. Sorption isotherms for MCPA for unamended and amended soils are shown in Figure 3, and, similarly to fluometuron, they can be divided into two adsorption levels: high to medium, observed in the case of the soil amended with AC, BC5, $\mathrm{OCl}$, and $\mathrm{BC} 6$, and low sorption of MCPA in unamended soil and soil amended with $\mathrm{BC} 1, \mathrm{BC} 2, \mathrm{BC} 3, \mathrm{BC} 4$, and OOW, which all had nearly the same sorption. A small increase in MCPA sorption can be observed for amendment with BC4 and BC3 as compared to the unamended soil (Figure 3b). The isotherms were also L-type.

Sorption data fit the Freundlich equation for most amended soils $\left(R^{2}=0.901-0.999\right)$ (Figure 3 ; Table 3 ). The $R^{2}$ criterion for the Freundlich equation was lower than those of the unamended soil and the soil amended with BC2 (0.704 and 0.784, respectively) and BC4 $\left(R^{2}=0.470\right)$. The MCPA Freundlich sorption coefficient in the unamended soil was $K_{\mathrm{f}}=0.10$ (Table 3), lower than values reported in the literature for MCPA of $0.24-2.21$ in unamended topsoils with $0.18-4.61 \%$ OC content. $^{5,22}$ 
Table 3. Sorption-Desorption Coefficients of MCPA in the Unamended Soil and Soil Amended with Different Biochars, Organoclay, Olive Mill Waste, and Activated Carbon

\begin{tabular}{|c|c|c|c|c|c|c|c|c|}
\hline soil & $K_{\mathrm{f}}\left(\mathrm{mg}^{1-1 / n f} \mathrm{~L}^{1 / n f} \mathrm{~kg}^{-1}\right)$ & $1 / n f$ & $R^{2}$ & $K_{\mathrm{d}^{-1}} 15\left(\mathrm{~L} \mathrm{~kg}^{-1}\right)$ & $K_{\text {fdes }}\left(\mathrm{mg}^{1-1 / n f} \mathrm{~L}^{1 / n f} \mathrm{~kg}^{-1}\right)$ & $1 / n f_{\text {des }}$ & $R^{2}$ & $\mathrm{H}$ \\
\hline$S$ & $0.10(0.07-0.14)$ & $0.54 \pm 0.18$ & 0.704 & $0.03(0.02-0.04)$ & $2.0(1.9-2.0)$ & 0 & 0.995 & 0 \\
\hline $\mathrm{S}+\mathrm{BC} 1$ & $0.12(0.11-0.14)$ & $0.76 \pm 0.07$ & 0.975 & $0.06(0.06-0.07)$ & $4.8(3.1-7.3)$ & 0 & 0.597 & 0 \\
\hline $\mathrm{S}+\mathrm{BC} 2$ & $0.03(0.02-0.05)$ & $0.67 \pm 0.24$ & 0.784 & $0.01(0.01-0.02)$ & $4.7(2.0-11)$ & 0 & 0.707 & 0 \\
\hline $\mathrm{S}+\mathrm{BC} 3$ & $0.29(0.24-0.35)$ & $0.52 \pm 0.10$ & 0.901 & $0.08(0.07-0.10)$ & $1.9(1.8-2.0)$ & 0 & 0.936 & 0 \\
\hline $\mathrm{S}+\mathrm{BC} 4$ & $0.75(0.50-1.13)$ & $0.38 \pm 0.23$ & 0.470 & $0.14(0.09-0.21)$ & & & & \\
\hline $\mathrm{S}+\mathrm{BC} 5$ & $4.13(3.70-4.60)$ & $0.59 \pm 0.07$ & 0.960 & $1.36(1.22-1.52)$ & $18.8(18.0-19.5)$ & $0.01 \pm 0.03$ & 0.008 & 0.01 \\
\hline S+BC6 & $1.90(1.71-2.11)$ & $0.66 \pm 0.07$ & 0.970 & $0.75(0.68-0.83)$ & $10.8(10.4-11.2)$ & 0 & 0.099 & 0 \\
\hline \multicolumn{9}{|l|}{$S+A C$} \\
\hline $\mathrm{S}+\mathrm{OCl}$ & $0.88(0.86-0.89)$ & $1.03 \pm 0.01$ & 0.999 & $0.94(0.92-0.96)$ & $1.0(0.9-1.2)$ & $0.94 \pm 0.05$ & 0.994 & 0.91 \\
\hline S+OOW & $0.16(0.15-0.18)$ & $0.62 \pm 0.04$ & 0.989 & $0.06(0.05-0.06)$ & $3.0(2.3-3.9)$ & 0 & 0.760 & 0 \\
\hline
\end{tabular}

By comparison of $K_{d}-15$ values, sorption of MCPA on the unamended and amended soil was lower than fluometuron sorption, which is consistent with the octanol-water partition coefficient $\left(\log K_{\text {ow }} ; \mathrm{MCPA}=-0.71\right.$, fluometuron $\left.=2.28\right)$, as has been reported for other herbicides' sorption, ${ }^{23}$ revealing the role of hydrophobic sorbate-sorbent interactions. MCPA was completely adsorbed to the soil amended with the activated carbon as observed for fluometuron.

According to $K_{\mathrm{d}}-15$ values (Table 3 ), sorption of MCPA followed the trend $\mathrm{S}+\mathrm{BC} 5>\mathrm{S}+\mathrm{OCl}>\mathrm{S}+\mathrm{BC} 6>\mathrm{S}+\mathrm{BC} 4>\mathrm{S}+\mathrm{BC} 3 \geq$ $\mathrm{S}+\mathrm{BC} 1 \approx \mathrm{S}+\mathrm{OOW}>\mathrm{S}>\mathrm{S}+\mathrm{BC} 2$, similar to fluometuron sorption, except for $\mathrm{S}+\mathrm{BC} 5, \mathrm{~S}+\mathrm{OCl}$, and $\mathrm{S}+\mathrm{BC} 2$. Sorption of MCPA on the amended soils was correlated with the surface area of the amendment, as was observed for fluometuron. Activation of BC3 at $200{ }^{\circ} \mathrm{C}$ for $2 \mathrm{~h}$ (BC4) slightly increased the sorption of the herbicide on the amended soil, as compared to the sorption on the soil amended with BC3. The effect of wheat ash on MCPA sorption was studied by Hiller et al., ${ }^{36}$ who observed a $10-$ 15 -fold increase in $K_{\mathrm{d}}$ values when a sandy soil and a sandy loam soil were amended with $1 \%$ ash. These authors suggested that the increase of MCPA sorption on the wheat ash amended soils was due to the organic carbon content of the ash and to the greater surface affinity for MCPA.

Amending the soil with $\mathrm{BC} 2$ decreased MCPA sorption on the soil; this effect was not observed for fluometuron and can be related to association of DOM molecules from amendments and the anionic herbicide, as was observed by Cox et al. ${ }^{12}$ for 2,4-D.

The incorporation of the HDTMA cation in the SAz1 clay provides a paraffinic structure to the clay, which creates a wide interlayer organic phase with high affinity for herbicides; this is presumably the reason for the high sorption on $\mathrm{S}+\mathrm{OCl}^{37}$ In the case of acids such as 2,4-D, it has been shown that some polar interactions between ammonium groups of the alkylammonium and carboxylic groups of the acid herbicide contributed to enhance the sorption. ${ }^{38}$ The change in the trend of the sorption of MCPA on the soil amended with the organoclay as compared to BC5 could be attributed to the anionic character of the herbicide at the $\mathrm{pH}$ of solution in equilibrium.

MCPA sorption to the soil amended with OOW was similar to the sorption on the soil amended with the biochar produced from hardwood sawdust (BC1). The effect of OOW on MCPA sorption has been previously studied, ${ }^{22}$ and an increase on MCPA sorption with the addition of olive mill waste to the soil was reported, which was attributed to the increase of OM from 1.6 to $4.3 \%$. However, although in this study a 3-fold increase of the soil OM content with the OOW addition was observed, the final OM content of the soil amended was $1.36 \%$, lower than the $4.3 \%$ reported in the previous study. The increase in sorption sites led by the increase in OM content would be counterbalanced by the association between the DOC and the herbicide molecules.

Desorption data of MCPA on the unamended soil and soil amended with $\mathrm{OCl}$ and $\mathrm{BC} 3$ fit the Freundlich equation $\left(R^{2}>\right.$ $0.9)$, but the fit was worse on the soil amended with olive mill waste, $\mathrm{BC} 2$, and $\mathrm{BC} 1\left(R^{2}=0.6-0.89\right)$, and did not fit for the soil amended with BC6 and BC5 (Table 3). For MCPA desorption the hysteresis phenomenon was also observed, $1 / n f_{\text {des }}$ values were lower than $1 / n f_{\text {ads }}$ in all the cases.

Leaching Studies. Fluometuron. Fluometuron was detected in all of the leachates of the columns handpacked with the unamended soil and with the soils amended with all of the sorbents on topsoil, except activated carbon. Breakthrough curves (BTCs) are shown in Figure 4, where two groups of curves can be observed: curves with low to medium (maximum concentration of the herbicide leached $4-11 \%$ ) or no leaching of the herbicide (e.g., soils amended with $\mathrm{AC}, \mathrm{BC} 5, \mathrm{BC} 6$, and $\mathrm{OCl}$ ) or curves showing a high or complete leaching of fluometuron and maximum concentration peaks of fluometuron $>20 \%$ (unamended soil and soils amended with $\mathrm{BC} 1, \mathrm{BC} 2, \mathrm{BC} 3, \mathrm{BC} 4$, and $\mathrm{OOW}$ ).

Leaching of fluometuron in the unamended soil was complete $(96 \pm 5 \%)$ (Table 4). Potter et al. ${ }^{39}$ reported a low runoff of fluometuron on plots planted with cotton due to the fast leaching of the herbicide. Essington et al. $^{3}$ also observed 5-53\% of the applied fluometuron leaching at a field site under natural rainfall conditions. Lower amounts of fluometuron were observed in the leachates of the soil amended with $\mathrm{BC} 5, \mathrm{BC} 6, \mathrm{BC} 4$, and $\mathrm{OCl}$ (Figure 4; Table 4), as compared to the unamended soil. This is in agreement with the higher sorption of fluometuron observed on the soils amended with those sorbents. Note that BC5 and BC6 are biochars with higher surface areas of 46.0 and $16.2 \mathrm{~m}^{2} \mathrm{~g}^{-1}$, respectively. The percent fluometuron leached was not affected by BC3, BC1, OOW, and BC2 used as sorbents, although the sorption study revealed higher sorption of the herbicide on the soils amended with these sorbents than on the unamended soil.

Lack of effect on fluometuron leaching with the addition of some biochars and OOW to the soil can be due to the content (Table 1) and interactions of DOC of the amendments with the herbicide, increasing its solubility and sorption reversibility and enhancing its movement, as other authors have reported. ${ }^{13,40,41} \mathrm{In}$ the case of $\mathrm{BC} 2, \mathrm{BC} 3, \mathrm{BC} 4$, and $\mathrm{BC} 6$ the observed displacement of the peak maximum concentration to lower volumes (Figure 4a) could indicate some possible association of fluometuron with some 

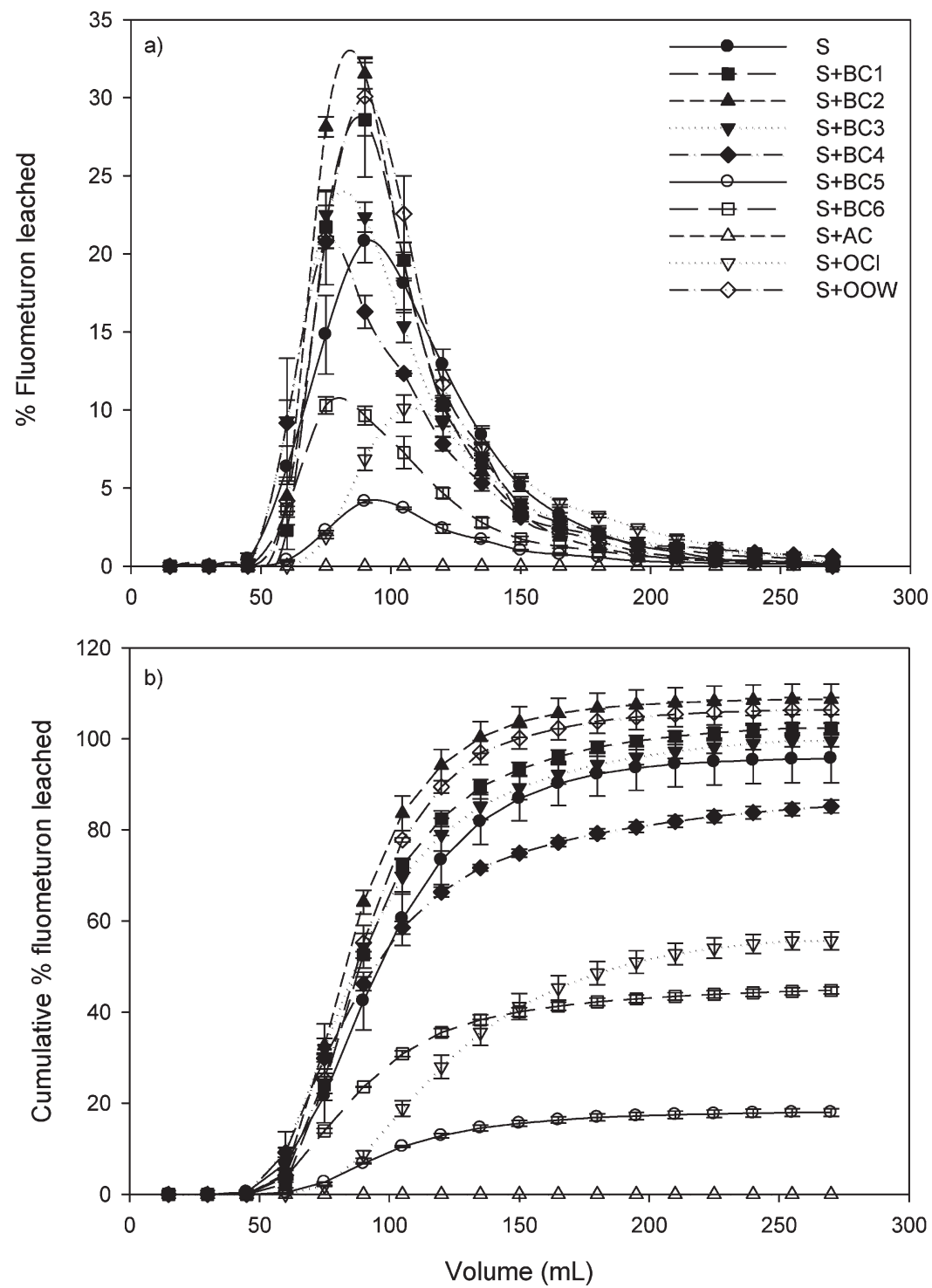

Figure 4. (a) Breakthrough curves (BTCs) of fluometuron leaching. (b) Cumulative fluometuron leaching in the unamended and amended soil handpacked columns.

Table 4. Percentage of Fluometuron Leached, Extracted, and Recovered from the Column Leaching Experiment

\begin{tabular}{|c|c|c|c|c|c|c|c|c|}
\hline \multirow[b]{2}{*}{ soil } & \multirow[b]{2}{*}{$\%$ leached } & \multirow[b]{2}{*}{ peak max concn $\left(\mathrm{mg} \mathrm{L}^{-1}\right)$} & \multicolumn{4}{|c|}{$\%$ extracted } & \multirow[b]{2}{*}{$\%$ total extracted } & \multirow[b]{2}{*}{$\%$ total recovered } \\
\hline & & & $0-5 \mathrm{~cm}$ & $5-10 \mathrm{~cm}$ & $10-15 \mathrm{~cm}$ & $15-20 \mathrm{~cm}$ & & \\
\hline S & $95.7 \pm 5.27$ & $2.31 \pm 0.26$ & & & & & & $95.7 \pm 5.27$ \\
\hline $\mathrm{S}+\mathrm{BC} 1$ & $102 \pm 1.07$ & $3.08 \pm 0.24$ & & & & & & $102 \pm 1.07$ \\
\hline $\mathrm{S}+\mathrm{BC} 2$ & $109 \pm 3.34$ & $3.60 \pm 0.13$ & & & & & & $109 \pm 3.34$ \\
\hline $\mathrm{S}+\mathrm{BC} 3$ & $99.6 \pm 1.29$ & $2.57 \pm 0.01$ & & & & & & $99.6 \pm 1.29$ \\
\hline $\mathrm{S}+\mathrm{BC} 4$ & $85.1 \pm 1.41$ & $2.09 \pm 0.04$ & 13.4 & 0.8 & 0.6 & 0.5 & 15.3 & $100 \pm 1.41$ \\
\hline S+BCE5 & $17.9 \pm 0.87$ & $0.45 \pm 0.01$ & $52.1 \pm 0.09$ & $0.93 \pm 0.26$ & & & $53.0 \pm 0.17$ & $70.9 \pm 0.26$ \\
\hline S+BC6 & $44.8 \pm 0.79$ & $1.05 \pm 0.03$ & 35.2 & 1.4 & 0.3 & 0.1 & 37 & $81.8 \pm 0.79$ \\
\hline $\mathrm{S}+\mathrm{AC}$ & & & $48.2 \pm 0.23$ & & & & $48.2 \pm 0.23$ & $48.2 \pm 0.23$ \\
\hline $\mathrm{S}+\mathrm{OCl}$ & $55.6 \pm 1.96$ & $1.13 \pm 0.14$ & $18.7 \pm 0.98$ & $0.87 \pm 0.12$ & $1.06 \pm 0.23$ & $1.47 \pm 0.04$ & $22.1 \pm 1.35$ & $77.7 \pm 2.33$ \\
\hline S+OOW & $106 \pm 2.75$ & $3.18 \pm 0.30$ & & & & & & $106 \pm 2.75$ \\
\hline
\end{tabular}

components of DOC from these biochars. ${ }^{41}$ This fact reveals the complexity and specificity of the processes involved in pesticide- soil-solution interactions in organically amended soils, primarily in cases of competition between DOC and herbicides for soil 

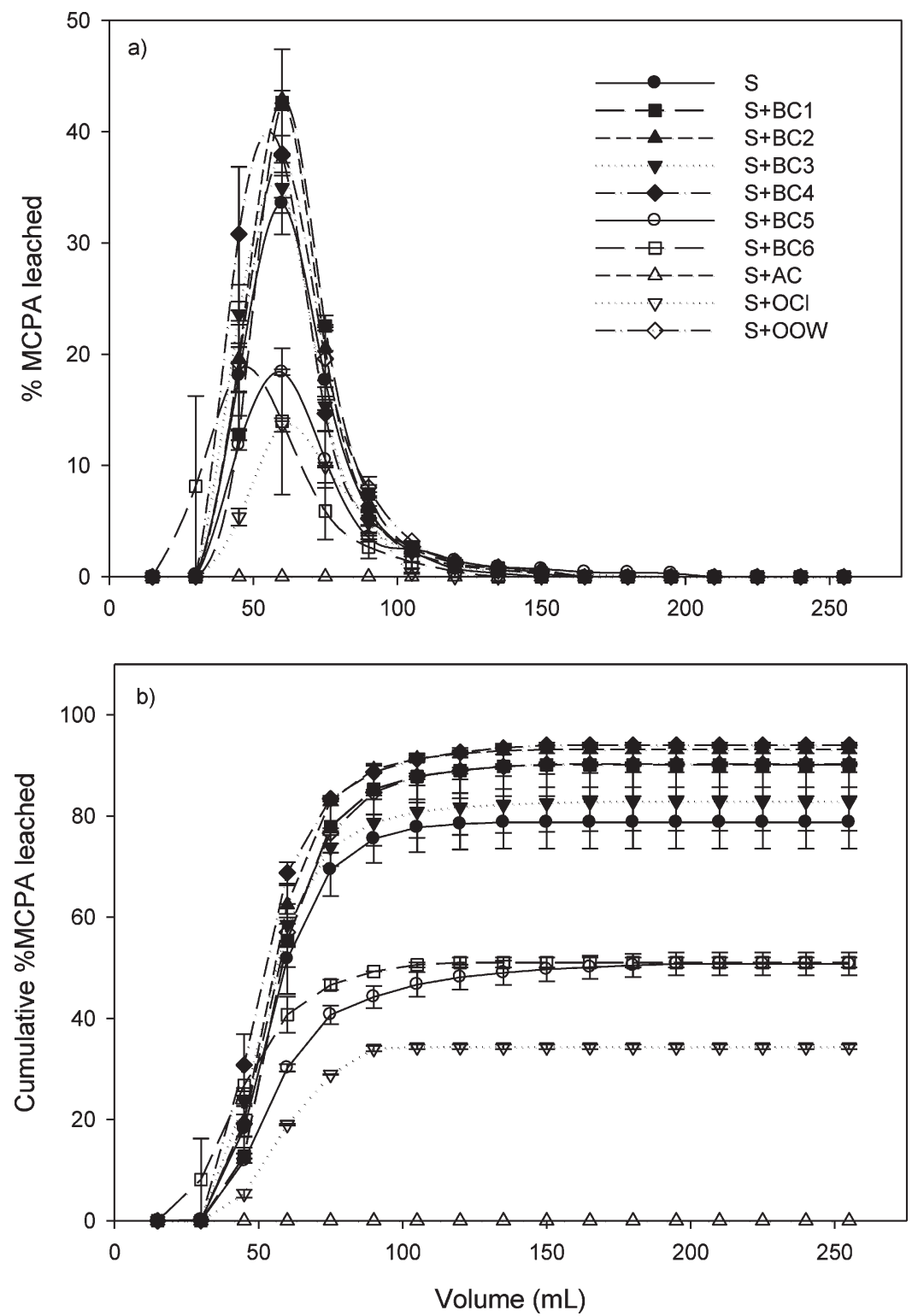

Figure 5. (a) Breakthrough curves (BTCs) of MCPA leaching. (b) Cumulative MCPA leaching in the unamended and amended soil handpacked columns.

surface interactions sites and even between soil surfaces and DOC for herbicides.

In Figure 4, a shift of the maximum concentration of fluometuron to larger pore volumes was observed only when $\mathrm{OCl}$ was used as sorbent. Gámiz et al. ${ }^{26}$ reported a similar behavior of fluometuron leaching in a soil amended with a Na-rich Wyoming montmorrillonite modified with spermine cation. The strong and specific sorption exhibited by OCl for ureic herbicides ${ }^{35}$ enhances $\mathrm{OCl}+$ soil herbicide retention and hence delays leaching.

The total leaching of fluometuron in columns filled with the soil unamended and amended are shown in Figure 4b, and they ranged from 0 to $100 \%$ and allow three different behaviors to be distinguished: (1) those amendments (OOW, BC1, BC2, and $\mathrm{BC} 3$ ) that slightly increased or decreased (BC4) the leaching with respect to unamended soil; (2) those amendments that largely decreased the amount of fluometuron leached out $(\mathrm{OCl}, \mathrm{BC} 6$, and BC5); and (3) active carbon that fully immobilized fluometuron in soils. The high porosity of AC may result in micropore adsorption, such as described by Pignatello and Xing, ${ }^{42}$ which is difficult to distinguish from chemisorption, and hence render bound residues. However, the low leaching in the cases of BC5, BC6, and $\mathrm{OCl}$ is probably due to some specific molecular interactions between herbicides and these sorbents. The enhanced retention in the case of BC5 and BC6 is probably due to interactions of DOC with soil surfaces, which, in turn, acts as a "bridge" between the surface and fluometuron, increasing its retention. ${ }^{43}$ In the case of $\mathrm{OCl}$, polar interactions between ammonium and carbonyl groups of similar herbicides have been shown.

MCPA. MCPA BTCs are shown in Figure 5, where three different types of curves can be observed: no leaching of the herbicide corresponding to the soil amended with the AC, low to medium leaching of MCPA with 5-10\% maximum concentration of the herbicide leached in the soil amended with $\mathrm{OCl}$, $\mathrm{BC} 5$, and BC6; and high leaching (maximum peak concentration $>30 \%)$ in the unamended soil and the soil amended with $\mathrm{BC} 1, \mathrm{BC} 2, \mathrm{BC} 3, \mathrm{BC} 4$, and OOW. A shift of the maximum 
Table 5. Percentage of MCPA Leached, Extracted, and Recovered from the Column Leaching Experiment

\begin{tabular}{|c|c|c|c|c|c|c|c|c|}
\hline \multirow[b]{2}{*}{ soil } & \multirow[b]{2}{*}{$\%$ leached } & \multirow[b]{2}{*}{ peak max concn $\left(\mathrm{mg} \mathrm{L}^{-1}\right)$} & \multicolumn{4}{|c|}{$\%$ extracted } & \multirow[b]{2}{*}{$\%$ total extracted } & \multirow[b]{2}{*}{$\%$ total recovered } \\
\hline & & & $0-5 \mathrm{~cm}$ & $5-10 \mathrm{~cm}$ & $10-15 \mathrm{~cm}$ & $15-20 \mathrm{~cm}$ & & \\
\hline$S$ & $78.7 \pm 5.16$ & $3.36 \pm 0.71$ & & & & & & $78.7 \pm 5.16$ \\
\hline $\mathrm{S}+\mathrm{BC} 1$ & $90.1 \pm 4.44$ & $4.75 \pm 0.51$ & & & & & & $90.1 \pm 4.44$ \\
\hline $\mathrm{S}+\mathrm{BC} 2$ & $93.1 \pm 0.75$ & $4.63 \pm 0.35$ & & & & & & $93.1 \pm 0.75$ \\
\hline $\mathrm{S}+\mathrm{BC} 3$ & $82.9 \pm 5.78$ & $3.70 \pm 0.32$ & $1.3 \pm 0.3$ & & & & $1.3 \pm 0.3$ & $84.2 \pm 6.08$ \\
\hline $\mathrm{S}+\mathrm{BC} 4$ & $94.0 \pm 0.53$ & $3.95 \pm 0.58$ & & & & & & $94.0 \pm 0.53$ \\
\hline $\mathrm{S}+\mathrm{BC} 5$ & $50.8 \pm 2.28$ & $2.06 \pm 0.07$ & & & & & & $50.8 \pm 2.28$ \\
\hline S+BC6 & $51.0 \pm 0.99$ & $1.94 \pm 0.29$ & $8.5 \pm 1.5$ & & & & $8.5 \pm 1.5$ & $59.5 \pm 2.49$ \\
\hline \multicolumn{9}{|l|}{$S+A C$} \\
\hline $\mathrm{S}+\mathrm{OCl}$ & $34.4 \pm 0.46$ & $1.50 \pm 0.06$ & & & & & & $34.4 \pm 0.46$ \\
\hline S+OOW & $90.3 \pm 0.39$ & $4.24 \pm 0.51$ & & & & & & $90.3 \pm 0.39$ \\
\hline
\end{tabular}

concentration of MCPA to smaller pore volumes was observed when the soil was amended with BC6 (Figure 5a), and no changes in the position of the highest concentration were detected in the soil amended with the other sorbents as compared to the unamended soil. The amount of MCPA leached in the columns handpacked with the unamended soil was lower than that of fluometuron, despite the lower sorption observed for MCPA in the sorption-desorption study. MCPA is considered to be a highly mobile herbicide, due to its high water solubility and low sorption to organic and inorganic components of the soil because of its negative charge and high polarity. ${ }^{44}$

Leaching of MCPA decreased when the soil was amended with the biochars BC6 and BC5 to 51\% of the amount of herbicide initially applied in both cases (Table 5). MCPA was not detected in the leachate from the soil amended with the activated carbon, and only $34 \%$ of the amount of MCPA applied was detected in the leachates from the soil amended with the OCl. However, leaching of MCPA increased as compared to the unamended soil when the biochars $\mathrm{BC} 1, \mathrm{BC} 2, \mathrm{BC} 3$, and $\mathrm{BC} 4$ and $\mathrm{OOW}$ were used as sorbents. The composition of dissolved organic matter influences the mobility of the herbicide MCPA. Haberhauer et al. ${ }^{45}$ observed an increase in MCPA leaching with the addition of humic acids to the eluent and retention of the herbicide when fulvic acids were added, and, as was pointed for fluometuron, the content of DOC of the amendments and interactions with MCPA can be responsible for the increase of herbicide leaching. In a previous study, the effect of organoclays and olive mill waste on MCPA leaching was studied. ${ }^{22}$ The use of both amendments decreased the amount of MCPA detected in the leachates as compared to the blank. However, the opposite effect has been observed in leaching of MCPA in the soil amended with the olive mill waste, which can be attributed to changes in the composition of the waste.

A slight shift of the maximum leaching concentration to lower volumes in BTCs was observed for the soil amended with BC4 and was more notable in the soil amended with BC6 (Figure 5). This effect observed in the soil amended with BC6 can be due to an initial increase of MCPA mobility by the formation of MCPA and DOC complexes; however, the amount of MCPA leached from this amended soil was lower than that from the unamended soil because of the higher sorption capacity of the amendment.

After the leaching experiment, MCPA was extracted from the soil column portions. Extraction of the herbicide was negligible because leaching was high or, in soils for which leaching was low, can be attributed to the fast degradation of the herbicide in soil, with half-life values reported of $<7$ days ${ }^{27,46}$ or to interactions of the biochars' DOC with soil surface (BC5, BC6) or MCPA with the organic cations at external surface of the modified clay, increasing sorption of the herbicide.

Addition of biochar as agricultural soil amendment was thought to be an efficient strategy to reduce the mobility in soil and risk of water contamination of the herbicides fluometuron and MCPA. However, our results showed that although in most cases addition of biochar increased sorption of the herbicides as compared to the unamended soil, leaching of the herbicides could be either reduced or promoted. Origin and C content of the organic matter of the amendment play important roles in herbicide sorption, and herbicide and DOC complex formation has to be taken into account and reveals the complexity and specificity of the processes involved in pesticide-soil-solution interactions in organically amended soils. In our study, biochar was not preincubated in the soil. However, it has been reported ${ }^{40}$ that, depending on the nature of the organic amendment and the soil surface, OM can change with residence time in soil, which can affect the herbicide-soil amendment interactions. Future studies should be carried out to determine the effect of biochar aged in soil on herbicide sorption interactions. Biochar and surface area are other important parameters to be considered for sorbent election. Our results showed that biochars with higher surface area favored higher sorption and lower leaching of the herbicides studied, similar to the effect of the use of the modified clay as soil amendment. OOW slightly increased herbicide sorption as compared to the unamended soil, but also increased leaching and reversibility due to its high DOC content. Therefore, previous studies on the effect of soil amendments on sorption and leaching of herbicides or on properties and composition of the sorbents are highly recommended before their application to agricultural soils to avoid the risk of water pollution because of the possible increase in herbicide mobility.

\section{AUTHOR INFORMATION}

\section{Corresponding Author}

*Phone: +34 95462 4711. Fax: +34 95462 4002. E-mail: macabrera@irnase.csic.es.

\section{Funding Sources}

We appreciate the financial support of Junta de Andalucía through Grupo PAIDI AGR-264 and of MICINN project AGL2010-21421 cofinanced by European Structural and social 
funds (FEDER-FSE) through the operative program 20072013 and the CSIC i-Link0025 project. A.C. thanks the MEC/ FECYT for a postdoctoral fellowship. Names are necessary to report factually on available data; however, the USDA neither guarantees nor warrants the standard of the product, and the use of the name by the USDA implies no approval of the product to the exclusion of others that may also be suitable.

\section{ACKNOWLEDGMENT}

We thank P. Velarde, B. Gámiz, and Dr. M. Real for their help in the laboratory studies and SSA measurements and Dr. P. Burgos for the DOC analysis.

\section{REFERENCES}

(1) Rice, P. J.; Rice, P. J.; Arthur, E. L.; Barefoot, A. C. Advances in pesticides environmental fate and exposure assessments. J. Agric. Food Chem. 2007, 55, 5367-5376.

(2) Rogers, C. B.; Talbert, R. E.; Mattice, J. D.; Lavy, T. L.; Frans, R. E. Residual fluometuron levels in three Arkansas soils under continous cotton (Gossypium hirsutum) production. Weed Sci. 1985, 34, $122-130$.

(3) Essington, M. E.; Tyler, D. D.; Wilson, G. V. Fluometuron behavior in long term tillage plots. Soil Sci. 1995, 160, 405-414.

(4) Baskaran, S.; Kennedy, I. R. Sorption and desorption kinetics of diuron, fluometuron, prometryn and pyrithiobac sodium in soils. J. Environ. Sci. Health, Part B 1999, 34, 943-963.

(5) Socias-Viciana, M. M.; Fernandez-Perez, M; Villafranca-Sanchez, M.; Gonzalez-Pradas, E.; Flores-Cespedes, F. Sorption and leaching of atrazine and MCPA in natural and peat-amended calcareous soils from Spain. J. Agric. Food Chem. 1999, 47, 1236-1241.

(6) Glaser, B.; Lehmann, J.; Zech, W. Ameliorating physical and chemical properties of highly weathered soils in the tropics with charcoal-a review. Biol. Fertil. Soils 2002, 33, 219-230.

(7) Spokas, K. A. Review of the stability of biochar in soils: predictability of O:C molar ratios. Carbon Manage. 2010, 1, 289-303.

(8) Preston, C. M.; Schmidt, M. W. I. Black (pyrogenic) carbon: a synthesis of current knowledge and uncertainties with special consideration of boreal regions. Biogeoscience 2006, 3, 397-420.

(9) Novak, J. M.; Busscher, W. J.; Laird, D. L.; Ahmedna, M.; Watts, D. W.; Niandou, M. A. S. Impact of biochar amendment on fertility of a southeastern coastal plain soil. Soil Sci. 2009, 174, 105-112.

(10) Sohi, S. P.; Krull, E.; Lopez-Capel, E.; Bol, R. A review of biochar and its use and function in soil. In Advances in Agronomy; Sparks, D. L., Ed.; Elsevier Academic Press: San Diego, CA, 2010; Vol. 105, pp 47-82.

(11) Celis, R.; Barriuso, E.; Houot, S. Effect of liquid sewage sludge addition on atrazine sorption and desorption by soil. Chemosphere 1998, 37, 1091-1107.

(12) Cox, L.; Cecchi, A.; Celis, R.; Hermosín, M. C.; Koskinen, W. C.; Cornejo, J. Effect of exogenous carbon on movement of simazine and 2,4-D in soils. Soil Sci. Soc. Am. J. 2001, 65, 1688-1695.

(13) Cabrera, A.; Cox, L.; Velarde, P.; Koskinen, W. C.; Cornejo, J. Fate of diuron and terbuthylazine in soils amended with two-phase olive mil waste. J. Agric. Food Chem. 2007, 55, 4828-4834.

(14) Marin-Benito, J; Sanchez-Martinez, M. J.; Andrade, M. S.; Perez-Clavijo, M.; Rodriguez-Cruz, M. S. Effect of spent mushroom substrate amendment of vineyard soils on the behavior of fungicides. 1 . Adsorption-desorption of penconazole and metalaxyl by soils and subsoils. J. Agric. Food Chem. 2009, 57, 9634-9642.

(15) Thevenot, M.; Dousset, S.; Hertkorn, N.; Schmitt-Kopplin, P.; Andreux, F. Interactions of diuron with dissolved organic matter from organic amendments. Sci. Total Environ. 2009, 407, 4297-4302.

(16) Cabrera Mesa, A.; Spokas, K. Impacts of biochar (black carbon) additions on the sorption and efficacy of herbicides. In Herbicides and
Environment; Kortekamp, A., Ed.; In Tech: Rijeka, Croatia, 2011; pp 315-340.

(17) Kookana, R, S. The role of biochar in modifiying the environmental fate, bioaviligy, and efficacy of pesticides in soils: a review. Aust. J. Soil Res. 2010, 48, 627-637.

(18) Spokas, K.; Koskinen, W. C.; Baker, J. M.; Reicosky, D. C. Impacts of wood biochar additions on greenhouse gas production and sorption/degradation of two herbicides in a Minnesota soil. Chemosphere 2009, 77, 574-581.

(19) Wang, H.; Lin, K.; Hou, Z.; Richardson, B.; Gan, J. Sorption of the herbicide terbuthylazine in two New Zealand forest soils amended with biosolids and biochars. J. Soils Sediments 2010, 10, 283-289.

(20) Yu, X. Y.; Pan, L. G.; Ying, G. G.; Kookana, R. S. Enhanced and irreversible sorption of pesticide Pyrimethanil by soil amended with biochars. J. Environ. Sci. 2010, 22, 615-620.

(21) Cabrera, D.; López-Piñeiro, A.; Albarrán, A.; Peña, D. Direct and residual effects on diuron behaviour and persistence following twophase olive mill waste addition to soil: field and laboratory experiments. Geoderma 2010, 157, 133-141.

(22) Cabrera, A.; Trigo, C.; Cox, L.; Celis, R.; Cornejo, J. A comparative study of the use of organoclay-based formulations and organic amendment to reduce the leaching of the herbicide MCPA in soil. Clean: Soil, Air, Water 2008, 36, 990-995.

(23) Delgado-Moreno, L.; Almendros, G.; Peña, A. Raw or incubated olive mill wastes and its biotransformed products as agricultural soil amendments - effect on sorption-desorption of triazine herbicides. J. Agric. Food Chem. 2007, 55, 836-843.

(24) Cabrera, A.; Cox, L.; Sadowsky, M.; Koskinen, W. C. Availability of triazine herbicides in aged soils amended with olive oil mill waste. J. Agric. Food Chem. 2008, 56, 4112-4119.

(25) Xu, S. H.; Sheng, G. Y.; Boyd, S. A. Use of organoclays in pollution abatement. Adv. Agron. 1997, 59, 25-62.

(26) Gámiz, B.; Celis, R.; Hermosín, M. C.; Cornejo, J. Organoclays as soil amendments to increase the efficacy and reduce the environmental impact of the herbicide fluometuron in agricultural soils. J. Agric. Food Chem. 2010, 58, 7893-7901.

(27) The e-Pesticide Manual. A World Compendium, ver. 4.1; Tomlim, C. D., Ed.; BCPC: Farham, U.K., 2007-2008.

(28) Cox, L.; Koskinen, W. C.; Yen, P. Y. Sorption-desorption of imidacloprid and its metabolites in soils. J. Agric. Food Chem. 1997, 45, $1468-1472$.

(29) Zablotowicz, R. M.; Locke, M. A.; Gaston, L. A.; Bryson, C. T. Interactions of tillage and soil depth on fluometuron degradation in a Dundee silt loam soil. Soil Tillage Res. 2000, 57, 61-68.

(30) Locke, M. A.; Zablotowicz, R. M; Steinriede, R. W.; Kingery, W. L. Degradation and sorption of fluometuron and metabolites in conventional tillage soils. J. Agric. Food Chem. 2007, 55, 844-851.

(31) Cox, L.; Velarde, P.; Cabrera, A.; Hermosín, M. C.; Cornejo, J. Dissolved organic carbon interactions with sorption and leaching of diuron in organic-amended soils. Eur. J. Soil Sci. 2007, 58, 714-721.

(32) Celis, R.; Barriuso, E.; Houot, S. Sorption and desorption of atrazine by sludge-amendment soil: dissolved organic matter effects. J. Environ. Qual. 1998, 27, 1348-1356.

(33) López-Piñeiro, A.; Cabrera, D.; Albarrán, A.; Peña, D. Cumulative and residual effects of de-oiled two-phase olive mil waste application to soil on diuron sorption, leaching, degradation, and persistence. Chemosphere 2010, 78, 139-146.

(34) Koskinen, W. C.; Calderón, M. J.; Rice, P.; Cornejo, J. Sorption-desorption of flucarbazone and propoxycarbazone and their benzenesulfonamide and triazolinone metabolites in two soils. Pest Manage. Sci. 2006, 62, 598-602.

(35) Aguer, J. P.; Hermosín, M. C.; Calderón, M. J.; Cornejo, J. Fenuron sorption on homoionic natural and modified smectites. J. Environ. Sci. Health, Part B 2000, 35, 279-296.

(36) Hiller, E.; Bartal, M; Milicka, J.; Cernansky, S. Environmental fate of the herbicide MCPA in two soils as affected by the presence of wheat ash. Water, Air, Soil Pollut. 2009, 197, 395-402. 
(37) Celis, R.; Trigo, C.; Facenda, G.; Hermosín, M. C.; Cornejo, J. Selective modification of clay minerals for the adsorption of herbicides widely used in olive groves. J. Agric. Food Chem. 2007, 55, 6650-6658.

(38) Hermosín, M. C.; Cornejo, J. Binding mechanism of 2,4dichlorophenoxyacetic acid by organo-clays. J. Environ. Qual. 1993, 22, 325-331.

(39) Potter, T. L.; Truman, C. C.; Bosch, D. D.; Bednarz, C. Fluometuron and pendimethalin runoff from strip and conventionally tilled cotton in the southern Atlantic coastal plain. J. Environ. Qual. 2004, 33, 2122-2131.

(40) Cox, L.; Fernandes, M. C.; Zsolnay, A.; Hermosín, M. C.; Cornejo, J. Changes in dissolved organic carbon of soil amendments with aging: effect on pesticide adsorption behavior. J. Agric. Food Chem. 2004, 52, 5635-5642.

(41) Celis, R.; De Jonge, H; De Jonge, L. W.; Hermosín, M. C.; Cornejo, J. The role of mineral and organic componentes in phenanthrene and dibenzofuran sorption by soil. Eur. J. Soil Sci. 2006, 57, $308-319$.

(42) Pignatello, J. J.; Xing, B. Mechanisms of slow sorption of organic chemicals to natural particles. Environ. Sci. Technol. 1996, 30, $1-11$.

(43) Cox, L.; Celis, R.; Hermosín, M. C.; Cornejo, J.; Zsolnay, A; Zeller, K. Effect of organic amendments on herbicide sorption as related to the nature of the dissolved organic matter. Environ. Sci. Technol. 2000, 34, 4600-4605.

(44) Felding, G. Leaching of phenoxyalkanoic acid herbicides from farmland. Sci. Total Environ. 1995, 168, 11-18.

(45) Haberhauer, J.; Temmel, B.; Gerzabek, M. H. Influence of dissolved humic substances on the leaching of MCPA in a soil column experiment. Chemosphere 2002, 46, 495-499.

(46) Crespín, M. A.; Gallego, M.; Valcárcel, M.; González, J. L. Study of the degradation of 2,4-D and MCPA at different depths in contaminated agricultural soil. Environ. Sci. Technol. 2001, 35, 4265-4270. 